Article

\title{
Coffeehouses (Re)Appropriated: Counterpublics and Cultural Resistance in Tabriz, Iran
}

\author{
Laleh Foroughanfar ${ }^{1,2}$ \\ ${ }^{1}$ Department of Architecture and Built Environment, Faculty of Engineering, Lund University, 22100 Lund, Sweden; \\ E-Mail: laleh.foroughanfar@arkitektur.lth.se \\ ${ }^{2}$ Centre for Middle Eastern Studies, Faculty of Social Sciences, Lund University, 22100 Lund, Sweden
}

Submitted: 31 May 2020 | Accepted: 28 August 2020 | Published: 12 November 2020

\begin{abstract}
Over the last decade, traditional coffeehouses have attracted increasing interest in the city of Tabriz, Iran, in the context of consistent state monitoring and restriction of public life-particularly so among non-Persian ethnolinguistic populations. Relying on a combination of ethnographic methods (observations, interviews, and visual documentation), this article explores the everyday life of two coffeehouses in Tabriz through a theoretical lens of third place, counterpublics, and everyday ethics of resistance. Coffeehouses are currently retaining functions as third places; cross-generational venues for preserving cultural, artistic, and linguistic identity as well as institutions of social defiance, resting on elaborate ethical codes and tacit social agreements. Through mechanisms of everyday ethics and cultural practices re-connecting to local history, cultural creativity, and language, insiders are distinguished from outsiders, serving to build trust, security, and solidarity in the context of Iranian state monitoring and restricted social space.
\end{abstract}

\section{Keywords}

coffeehouses; counterpublics; cultural resistance; everyday ethics; Iran; third place

Issue

This article is part of the issue "Built Environment, Ethics and Everyday Life" edited by Mattias Kärrholm (Lund University, Sweden) and Sandra Kopljar (Lund University, Sweden).

(C) 2020 by the author; licensee Cogitatio (Lisbon, Portugal). This article is licensed under a Creative Commons Attribution 4.0 International License (CC BY).

\section{Introduction}

In post-revolutionary Iran, public spaces are typically gender-segregated and under considerable surveillance. In large cities such as the capital city of Tehran, the control of public spaces has triggered a subversive life and assemblies in homes, underground concerts, fashion shows, and home galleries (Moeini, Arefian, Kashani, \& Abbasi, 2018). Surveillance can be even more severe in other cities, where traditional and religious norms further enforce the social control of public life. In this context, the institution of coffeehouses (qahva-kāna) in Tabriz has taken a particular significance (among men, since coffeehouses remain heavily male-dominated). The traditional coffeehouse-as distinct from the 'Westernised' cafés-has a long history as a vital institution and communal core of public life. It shows all the characteristics of 'third places,' to draw on Ray Oldenburg's (1989) often cited study The Great Good Places. As shall be argued in this article, however, in Tabriz, the largest city in the Turkish-speaking Azerbaijan region of Iran, such third places also serve functions of everyday resistance. Although AzerbaijaniTurkish is the spoken language in the region, it is prohibited in schools and formal education. Thus, coffeehouses are stages for counterpublics in nourishing Turkic cultural and linguistic values-restricted through the Persianification policies of the state.

Based on fieldwork in two distinct coffeehouses, this article examines the history and use of coffeehouses in contemporary Azerbaijan region, and the role they play in the processes of resistance to state-oriented narratives and processes of neo-liberal urban development, through the everyday (re)construction of shared values and collective memory. Shedding light on intersecting ethnical, socio-economical, and political features 
in constructing everyday ethics and solidarity, the article explores the recent attentiveness among the younger generations for coffeehouses. Even so, the historical pattern of coffeehouses as mono-gendered environments contributes to reinforcing gender-segregating policies of the government. This two-fold nature of coffeehouses, I argue, brings the emancipatory potential of the coffeehouses into question.

The article falls into five main sections. Following this introduction, Section 2 provides a background, discussing the historical and socio-political functions of coffeehouses in the context of urban development policies. Section 3 discusses theoretical notions of 'place' (public and private space; place identity; everyday resistance) and method. Section 4 discusses the findings, elucidating the everyday life, socio-cultural, and political functions of the coffeehouses. Section 5 provides a brief conclusion.

\section{Coffeehouses: Politico-Historical Legacies and Urban Contexts}

Originally introduced through Ethiopia, coffee spread to the countries of Southwest Arabia in the 16th century (Toussaint-Samat, 2009a, p. 532). The first public coffeehouse opened in Ottoman Turkey, while the former consumers of the beverage were members of Sufi orders who used coffee as a stimulant during all-night vigils and rituals (Wohl, 2017). With the growing public sentiment about the medical benefits of coffee (Hattox, 1985, p. 17), its popularity increased. On the other hand, coffee also stirred controversy. Pious critique alleged coffee to violate Islamic law against intoxicating substances as well as considering coffee as an unlawful innovation of doctrine (bid'a; Hattox, 1985, p. 6). Although pilgrims returning from Mecca introduced the idea of the coffeehouse in Egypt, Syria, and elsewhere, as a result of such religious disapproval, 1511 coffeehouses were temporarily closed in Mecca (Hattox, 1985, p. 36). Adding to such theological opposition, coffeehouses became a source of mundane political concern as well, as they were regarded as potential sites of political and oppositional discussion.

The first coffeehouses in Iran (former Persia) probably appeared during 16th century in Tabriz, Qazvin and new capital of Isfahan during Safavid rule (Encyclopædia Iranica, 2011). Coffeehouses were exclusive places of leisure for male notables and the upper-middle class of Safavid urban society. With increasing trade and urbanisation, coffee became cheaper and thus accessible for non-elites. Coffeehouses became places of contemplation (Matthee, 1994), education, music, and storytelling (Encyclopædia Iranica, 2011). As described by Rudi Matthee, in his travel accounts from the 17th century, Sir John Chardin reports on the unique freedom of speech in coffeehouses during the Safavid era. Other documents, however, indicate Shah Abbas's interest in controlling coffeehouses by sending mullahs (religious leaders) to provide moral and religious training and curb antiShah political debates. Chardin describes the activities in coffeehouses as follows:

People engage in conversation, for it is there that news is communicated and where those interested in politics criticise the government in all freedom and without being fearful since the government does not heed what the people say. Innocent games...resembling checkers, hopscotch, and chess, are played. It often happens that two or three people talk at the same time, one on one side, the other on the opposite, and sometimes one will be a preacher and the other a storyteller. (Matthee, 1994, p. 24)

The very first coffeehouses were known as 'academies of knowledge' (madrasat al-'olamā; Encyclopædia Iranica, 2011), located by the main squares, theological seminaries (madrasas) and mosques (Matthee, 1994). The location indicates how coffeehouses were integral to the social everyday life of men (and men only) of knowledge and power. In late Safavids times, with the expansion of the commercial centres of Bazaars, coffeehouses were established in the vicinity of caravanserais and public baths. Here, coffeehouses became associated with guilds, functioning as employment agencies and forums for socio-political and economic affairs. As Wohl (2017) points out, in the late 19th century, Russian and Balkan immigrants who settled in Istanbul brought with them the new custom of teahouses. At about the same time in Iran, tea came to replace coffee as the most popular beverage. Even so, the term qahva-kāna has continued to be used interchangeably with čāy-k̄āna (Encyclopædia Iranica, 2011). In short, today 'coffee houses' are in effect tea houses, since coffee is not served anymore.

Tabriz has served as the capital for several Iranian dynasties (and the seat of the crown prince during Qajar times). Besides being a political centre, Tabriz was located on the Silk Road, as a crossroads between the Ottoman Empire and Russia. This established the Grand Bazaar of Tabriz (listed as a world heritage by UNESCO since 2010) as a socio-political and commercial hub. With this, it also became a centre for mobilising social, political, and religious movements, in past as well as recent Iranian history. In this context, coffeehouses in Tabriz assumed functions vital to both everyday life and social protests, such as the Tobacco Protest, in 1890, and the Constitutional Revolution, in 1911. As the contemporary historian Nahidiazar (2006) pointed out, during the historical Tobacco Protest, Zainab Pasha, a militant woman, together with forty women of Tabriz, started an armed struggle against the tobacco concession granted in 1890 by the Qajar Nasir al-Din Shah of Iran to Britain. According to this colonial concession, Britain was granted to control overgrowth, sale, and export of tobacco. However, with the intense resistance of people in cities like Tabriz, Nasir al-Din Shah was forced to cancel the tobacco credits that were given to Britain. In parallel, Zeinab Pasha and her female fellows organised several revolts against the brutal feudal system, which in support 
of the local governors had caused a long period of famine and deprivation known as the 'bread shortage' in Tabriz. In both incidents mentioned above, Zainab Pasha and her female rebellions were actively choosing the Grand Bazar and coffeehouses to mobilise the male retailers and workers against the oppression and also break the patriarchal social norms (Nahidiazar, 2006). According to the oral historian Mashalallah Razmi (2018), coffeehouses similarly became venues for news dissemination, (elite) political discussion, interactions among ordinary people, and a nucleus of resistance against the Pahlavi monarchy before and during the Islamic Revolution of Iran in 1978-1979 (Razmi, 2018, p. 114). With the Islamic Revolution, however, followed a drastic reduction of coffeehouses, brandished by the authorities as places of potential insurgence and questionable public morals, crime, and health.

Despite their importance for the historical memory of the city, the majority of coffeehouses today largely function as a gathering place for guild members and lower socio-economic strata. Not only do political authorities continue to view coffeehouses with suspicion as sites of potential political activity, they are also stigmatised with a 'low-class' repute for housing rural migrant labourers or urban poor. As a sum effect, they draw little attraction among broader populations. Many establishments have closed down due to falling profitability, or faced demolition in the wake of urban renewal processes during the last decades.

\subsection{Coffeehouses in the Shadow of Unequal Urban Development}

With its population exceeding 1.5 million, Tabriz is the largest city and main economic magnet of the Eastern Azerbaijan province of Iran. Similar to other metropolitan areas in the Global South, the city is subject to uneven and unjust urban developments and socioeconomic segregation: About one-third of its population lives in informal settlements (Zangiabadi \& Mobaraki, 2012). Such segregation partially originated in the economic recovery plan after the Iran-Iraq war (1980-1988) and in line with the government's centralistic socio-economic and political policies. Aspiring economic development and opportunity for the unemployed youth as well as meeting the housing shortage for a rapidly growing and urbanising population, the government relaxed the regulations for housing construction. With the exception of some affordable state-run housing projects, the market was simultaneously state-subsidised, deregulated, and commercialised. This, in combination with the oil rents based economy rising conjointly with the growing oil price during the previous three decades, had a severe effect on real estate development and commodification of housing and urban spaces (Kheiraldin, Taghvayi, \& Imani Shamlou, 2013). This stimulated the private, profit-oriented sector to initiate large-scale projects and hence the creation of a new economic middle and upper class. The housing policy was further facilitated by economic support from private banks through long-term mortgages (Sadighi \& Salek, 2018). This coincided with changes in urban planning policies and land use regulations allowing municipalities to compensate budget deficits through the renewal projects (Kamrava, 2012). Tabriz was among the pioneering cities for such processes, currently holding second place in the ratio of high rise buildings in the country (Dehgan, 2017).

The deregulation carried three important consequences for Tabriz. Firstly, the fabric of the inner city was thoroughly transformed. Single houses were demolished and replaced with new, high-rise, commercial, and office buildings combined with residential apartments, generating considerable profits for landowners and developers. Secondly, parallel to the transformation of the inner city, the urban municipal district drastically expanded at the expense of the fruit gardens surrounding the city (for which Tabriz was famous), destroying the natural ecosystem. Thirdly, the rapid growth of the city stimulated population mobility. In pursuit of work and settlement, migration from smaller towns and villages rose sharply, establishing a growing underclass of informal settlers in the city margins.

Taken together, these processes have radically changed the urban morphology and demography of the city. During the last decades-and parallel with global waves of neo-liberalism-spatial injustice has swiftly aggravated. Privatisation and 'mallification' has resulted in the proliferation of luxurious residential and commercial buildings, while public and green spaces are shrinking by the day and class-divisions are deepening. Overestablishment, commercialisation, and inflation have largely polarised the city and turned significant parts of the city into areas for upper/middle-class residence and consumption, able (and willing) to spend their new prosperity in shopping malls and Westernised cafés.

\section{Theoretical Reflections on Place and Everyday Resistance}

In this context, I shall argue, coffeehouses have recently come to re-emerge as a counterpublics in the city of Tabriz. They do so, in part, as third places in Ray Oldenburg's (1989) sense. In Oldenburg's (1989) understanding, third places are environments between home and work where citizens assemble in spontaneous and informal settings. He discussed places such as cafés, pubs, barbershops, and laundry rooms as social spaces of daily encounters. But certain coffeehouses also have come to reclaim a distinct socio- and cultural-political significance. Apart from their 'Oldenburgian' leisurely functions, they also cater to a new segment of the population, finding (and forging) in the coffeehouses an arena for nurturing localised, counter-hegemonic social and cultural affinity, integrated into everyday life and professional endeavour. Expanding on such functions, the following section considers theoretical perspectives on 'place' con- 
cerning notions of 'public' and 'private,' in regard to power relations, counter-hegemonic struggle, and everyday resistance.

\subsection{The Publicness of Places?}

In the Western context, Habermas (1991) has identified coffeehouses and cafés as historically central for the emergence of a 'public sphere.' Habermas (1991) defines this sphere as an (ideally) inclusive venue for critical and democratic engagement in public and political deliberation. This definition of 'the public sphere' has also been the backbone for the conceptualisation of public space in urban design and planning discourse. It is, however, questionable to what extent this is universally applicable to varying socio-political contexts; to what extent every citizen de facto is able to engage democratically in such 'publics.' Nancy Fraser (1990) formulates critical reflections on the notion of a universal 'public sphere' for the practice of democratic citizenship. She understands democracy as a complex and contested notion, which varies in meanings and forms (Fraser, 1990). Suggesting a feminist revision of Habermas' theory, Fraser (1990) points to the hegemonic and dominant relations traversing 'the public sphere,' at the expense of alternative publics. She identifies the potential of "subaltern counterpublics" where marginalised groups create their distinct public spheres (Fraser, 1990, p. 67).

In line with Fraser, urbanist Margaret Crawford (1995) expands the notion of counterpublics into the realm of public space, identifying how informal micro publics (sidewalks, parking lots, swap meets, etc.) become particularly significant when access to public space is regulated, gendered, and monitored by norms and power systems. This invites critical perspectives on the dichotomy of public and private. Grounded in a liberal bourgeoisie concept of the public sphere (Crawford, 1995), public and private spaces have typically been understood as distinct and contrasting social realms. However, the emergence of counterpublics and multiple publics effectively blurs the boundaries of public and private through everyday lived experiences, reproducing multiple sites of expression (Crawford, 1995, p. 5).

Also, following the 'publics' and public sphere discussion, Warner (2002) distinguishes between 'the' public as a social totality, that of people in general, and 'a' public, a concrete audience bounded with an event or shared physical space. Warner (2002) draws attention to the discursive aspect of ' $a$ ' public, which, in practice, appears as 'the' public. In order to imbue a sense of belonging or carry emancipatory functions, a public must be self-organised and upheld through discourserather than external or formal processes such as participating in democratic processes through voting. Warner (2002) argues that if the ways of being public are organised through powerful state institutions and/or religious establishments, it will forward totalitarianism: in his words, "a non-kin society organised by bureaucracy and law" (Warner, 2002, p. 414). In contrast, Warner (2002, p. 416) argues, there are meanings, pieces of knowledge, symbols, and traditions, which are discursively shaping publics as subaltern counterpublics concerning state power.

Indeed, in post-revolutionary Iran, the intermingling of public and private life is a fundamental characteristic of everyday life, most notably so among marginalised segments of the population such as women and ethnic minorities. For such groups, the capacity for public participation and visibility is heavily constricted and marred with constant negotiations and manoeuvring. The attempts of sustaining a public life require lowprofile social arenas, hidden from the gaze of public norms and the state-centred regulations, forging alternative publics in the form of domestically organised assemblies. Basements and garages are transformed into arenas for underground music. Homes turn into cafés and galleries. Social (and romantic) life in private cars complicates 'private' vis-à-vis 'public.' To quote Paul Gilroy (2003, p. 387), public yet hidden spaces "make room for those whose opinions are marginal or antagonistic to the mainstream or whose spatial freedom is limited by law, hostility or harassment."

\subsection{Place and Everyday Resistance}

Place, in its geographical definition, is the combination of spatial and social relations; it is a "social space" (Cresswell, 1996, p. 3), an "interpretative frame through which people measure their lives, evaluate others, take political positions and just make sense" (Gieryn, 2000, p. 467). Thus, norms and rules as well as deviance are produced in places (Cresswell, 1996, p. 25). It is in place that certain behaviours become accepted by others, creating a sense of meaning and belonging. Hence, places also create and affirm social stratification. As centres of contested meanings, places construct and reveal difference, creating insiders and outsiders. Or, to draw on Warner (2002, p. 418), "difference is a direct implication of the self-organisation of the public as a body of strangers united through the circulation of their discourse, without which public address would have none of its special importance." That is why the metaphor of conversation, answering, talking back, and deliberating is significant in the interactive social relation of a public (Warner, 2002, p. 420). Hence, belonging rests on fulfilling expected behaviours and internalising social values. In failing to do so, one becomes "out of place" (Cresswell, 1996, p. 26). Such perspectives also invite power perspectives. As Cresswell describes, "the meaning of a place is subject to particular discourses of power, which express themselves as discourses of normality...the meaning of a place, then, is (in part) created through a discourse that sets up a process of differentiation [between us and them]" (1996, p. 60).

De Certeau (1984) draws attention to the constant struggle between dominant and dominated through pro- 
cesses of navigation, negotiation, and appropriation of place. People's mundane routines in consuming places shape distinct interpretations, based on group-specific social, political, and historical imaginations. In this sense, despite being subject to dominance, ordinary people are not passive members of society. Through mundane practices in the cracks of dominant strategies and hegemonic structures, they forge agency and tactics based on "the necessity to survive and improve life" (Bayat, 2010, p. 58): the homeless building a shelter; the street vendor appropriating a sidewalk; or, in application to this study and in response to centralised, politico-cultural dominance, localised cultural practices and group-specific understandings of place, belonging, and everyday ethics (produced in the Coffeehouses) have the potential of establishing counter-hegemonic meanings as survival tactics.

Resistance is not necessarily intentional. Cresswell (1996, p. 24) notices how counter-power practices often take the shape of non-planned 'transgressions' of normative boundaries, providing "tactics for resistance to established norms." This sits well with Bayat's (2010, p. 44) reflections of everyday resistance: Global restructuring has thoroughly changed the terrain of political struggle and subject formation. In this setting, ordinary peoplethe urban poor and the subaltern-establish channels through the core of power in everyday practices, and especially so in highly constrained political societies. Bayat (2010) conceptualises such aspirations as 'nonmovements' among non-collective actors. He speaks of 'quiet encroachments' on the terrains of power: the nonformal but prolonged, direct actions to acquire basic needs in a quiet and unassuming illegal fashion (Bayat, 2010, p. 45). Such everyday encroachments have transformed the large cities of the Middle East (and beyond), "generating a substantial outdoor economy, new communities, and arenas of self-development in the urban landscapes" (Bayat, 2010, p. 15). Despite poverty, destitute conditions, and political dominance, subordinate social groups are exercising an "art of presence" through everyday practice (Bayat, 2010, p. 26). They do so without formal engagement in social struggle or joining party politics (Moeini et al., 2018, p. 2), yet asserting agency (Miraftab, 2012, p. 1207).

With a geographical take on place as a socio-material event and encounters, Popke (2009) brings in the matter of 'ethics,' not in the meaning of universal norms or juridical constructs nor morality, but as a form of 'ethos.' According to Popke (2009, p. 84), "such an ethos works toward encounters that open us to a generous sensibility, one that might be capable of re-enlivening our affective engagements with others and fostering a heightened sense for what might be possible." Ethics in its broader definition creates a platform for collective performance, caring for others, and solidarity. Relating to the philosopher Jean-Luc Nancy's (2000, p. 42) conceptualisation of co-existence as an 'in-common,' Popke (2009, p. 85) understands ethics as a "site of ethical responsibility and political efficacy," as opposed to ethics of neoliberal gov- ernmentality (Popke, 2009, p. 84). Or, as pointed out by Bruce Braun and James McCarthy (2005, p. 808), necessary for the establishment of an ethical social space is "a political language and imagination that takes as its starting point the 'being-with' or 'being-in-common' that Nancy so brilliantly locates at the centre of human existence." Concerning the cases in this article, the construction of such ethical sites of responsibility and political imaginations may increase citizens' capacities to act.

\subsection{A Note on Method}

The mixed-design, ethnographic methodology for this research included interviews, visual documentation, and observation. The fieldwork took place during two field visits in 2014 and 2016, followed up with regular contacts with the main participants. The study was conducted in six coffeehouses in different socio-economical zones of Tabriz, resulting in about thirty interviews. Subsequently, data from two of the best-known and iconic coffeehouses were chosen for this article, here designated as Alif and $\mathrm{Ba}$, with four interviews in each. The choices were based on: (1) being favoured by both intellectuals/artists and 'traditional' regulars; (2) harbouring strong intergenerational relations; and (3) displaying relaxed traditional norms as concerns female visitors. As a female researcher conducting a study in male-dominated places, I faced several obstacles such as choosing the accurate time for interviews and not drawing unwarranted attention. Such limitations underscored the two-fold nature of the coffeehouses and their restrictions regarding equal gender accessibility. Nevertheless, to overcome such hurdles, three male research assistants facilitated the fieldwork in various stages. This included 'chaperoning' as well as introducing me to coffeehouse owners and regulars. The names, locations, and professional titles of participants, as well as establishments, have been altered in this article to ensure confidentiality and personal security.

\section{Coffeehouses: Much More than Smoking Hookah and Drinking Tea}

Coffeehouse Alif was built some 90 years ago inside the Grand Bazaar, while coffeehouse Ba is found in the basement of a downtown building. Both take on a low profile, with no signs drawing attention. The physical and interior features and sitting patterns are similar, dividing the hookah smokers (the older generation) from cigarette smokers (mostly the younger/professionals). Both places are flavoured with vintage elements such as old-style pictures, radio, and traditional instruments-but also a television screen on the wall and Wi-Fi Internet access. Mirrors on the walls enhance the visual space and provide the owner with an inconspicuous means of monitoring the guests. Wooden tables and benches furnish the room along the walls and the central space remains empty. One section is devoted to the traditional reg- 
ulars, mostly middle-aged or senior male workers or entrepreneurs. Usually sitting opposite them, another group or regulars comprises a younger generation of artists, filmmakers, writers, and other cultural workers.

The main difference between the two coffeehouses concerns location and atmosphere. The location in the Grand Bazaar, starkly contrasting with the modernised city, has attracted locals as well as tourists to Alif. Its popularity among the artists partly has its background in the international photography festival Firoozeh, where many participants documenting the Bazaar used Alif for resting, drinking tea, and socialising with the locals. This also meant that female tourists visited Alif, gradually relaxing the long-standing social norms defining coffeehouses as exclusively male spaces. This expanded the clientele, establishing Alif as a hub for artwork, exhibitions, and professional meetings in parallel to its 'traditional' function as third place. Ba is larger and it is well-known both for its relaxed environment created by the owner and as a historical hub for intellectuals before the revolution. The owners in both coffeehouses have significant roles in the popularity and diversity of the places.

\subsection{Coffeehouses as Third Place}

Both coffeehouses fulfil Oldenburg's (1989) criteria for third places. They are available at different times of the day, for different groups of individuals, with different interests, occupations, and socio-economic backgrounds. Both coffeehouses meet the needs for sociability and relaxation in the gaps before, between, and after the duties of mundane life. They offer a wide range of activities, from smoking hookah and engaging in conversations or work-related meetings to watching football matches, reading books, and working on laptops. The latter two activities are new trends, as a younger generation of artists and professionals have appropriated the coffeehouses. Coffeehouses hence are the interstices of the privacy of home and the publicness of work (both associated with pre-defined responsibilities and obligations). Being neither a home nor a place of work makes the coffeehouses "what the home is not" (Oldenburg, 1989, p. 39). Ahmad, a senior participant, voiced the experience of the flexibility and multi-functionality of the coffeehouses:

Some of us have been regulars of this coffeehouse for 60 years. It is a second home for us. Many of us can make our own hookah at home, but home is a limited place with limited activities, while the coffeehouse is a social place where people spontaneously engage in talking to each other and sharing their private issues and problems.

Individuals come and go as they desire. No one is required to act as a host, and all feel comfortablewhat Oldenburg coined as "neutral ground" (Oldenburg, 1989). Visits vary in time according to interests and social groupings but peak in late evenings, as visitors tend to gather after work and before heading home. Prices are considerably lower compared with the Westernised cafés and coffeehouses offer a different temporal rhythm. In the words of a 33-year-old visitor:

In the coffeehouse, I can choose either being with friends or sitting alone and thinking. It depends on my mood and need. But I know that I can sit as long as I want and no one will ask me to leave.

\subsection{Scenes for Cross-Generational and Counterpublic Attachments}

Besides the third place characteristics, the coffeehouses serve important functions as arenas for socio-political, cultural, and narrative processes responding to statepolitical hegemonic narratives as well as recent urban development. A socio-cultural and spatial consequence of the imposed top-down urban interventions described in previous sections is the loss of historical memory and collective-local identity of the city. In the context of drastic transformation, coffeehouses are among the scarce institutions to have survived as "vehicle[s] for constructing shared beliefs and identities" (Wohl, 2017; cf. Mills, 2010). As we have seen, a central experience among the regulars is the feeling of 'being at home' or considering coffeehouses as a 'second home.' There are particularly strong connections between the place and its regulars. The low profile (Oldenburg, 1989) characteristic of the coffeehouses, as manifest in the physical setting and furnishing, further contributes to the informal, intimate, tranquil, and welcoming character which is not available in the Westernised cafés. In the words of a 78-year-old man who has moved from downtown to one of the newly developed neighbourhoods in outskirts of the city:

Even though it takes a long time to commute from home to Alif, I do it every day. I live in a small apartment where there is no place to hang out outside the house. I do not know anyone and if I become sick or die, no one will notice. The coffeehouse is the place where my friends gather and care about me, without the coffeehouse I cannot live.

Coffeehouses have also become environments where artists without official affiliations or financial support to lease an office can run their professional life. This new category of visitors has come to side with the 'traditional' category of senior regulars, initiating tacit yet pivotal negotiations of non-written rules, territoriality, sitting, and smoking patterns, as well as time of attendanceall defining the temporal and social rhythm of the place. Despite the old-style furniture and esprit of the coffeehouses, usage of digital technologies such as tablets, laptops, and cameras, as well as Wi-Fi by the younger and arty customers, is today widely disseminated in coffeehouses. Such changes notwithstanding, the atmosphere 
remains friendly and the interviews indicate no tensions between the two categories of regulars:

A laptop is an essential tool for my job. I often sit in the coffeehouses and work. The senior regulars watch me curiously and ask questions to learn more about it. Sometimes they wonder about my camera equipment, and why I use several lenses on my camera. But the interesting thing is they know how to keep distance to show respect and also not to disturb.

The cross-generational composition of the visitors makes coffeehouses unique places in contemporary Tabriz, providing arenas for socio-cultural interchanges on an everyday basis. This concerns the reproduction of local history as well as linguistic identity, underscoring the function of the coffeehouses as counterpublics. As distinct from the cafés, the coffeehouses override the class and generational distinctions polarising the city. The ambition to associate such places with notions of 'authentic' culture is manifested in the interior decoration and arrangement of the coffeehouses. Old pictures of the forefather of the owner, local leaders of the Constitutional Revolution, and vintage furniture contribute to root the place in local history and shared cultural codes. The sense of counter-public attachments is maintained by the informality and intimacy, embodying shared values and historical memories. Through intergenerational exchanges, historical memory, linguistic practice, and social imagination assemble, as will be developed in the following section.

\subsection{Cultural-Linguistic Resistance}

Verbal interaction and cultural-linguistic identity are important aspects of the distinctive character of the coffeehouses. Socialising rather than drinking tea or smoking hookah is the main interest of the regulars. Conversation, Oldenburg $(1989$, p. 27$)$ points out, is the most "communal mode of connection" and "engages the members on various personal and collective levels." But in the context of Azerbaijan, such functions attain a particular baring.

Language regulation has been central in the state's efforts to homogenise Iranian society and manufacture a unified 'national identity,' before as well as after the Islamic Revolution of 1979 , as non-Persian mother tongues are banned from public education. In the Azerbaijan region of Iran, the Azerbaijani-Turkish language is spoken in private, daily exchanges, while excluded from all official capacities. In reaction to such politics of marginalisation, Azerbaijan in recent years has witnessed invigorated bottom-up efforts to dynamise the vitality of the local language. Cultural production has seen a distinct revival through publications of books, magazines, and podcasts in Azerbaijani-Turkish, despite all limitations and disruptions. Also, theatre and music groups in Azerbaijani-Turkish are receiving increasing recognition. In this context, the coffeehouses play a crucial role in preserving and developing the Turkic culture and language.

One of the pre-modern traditions within coffeehouses was storytelling, particularly during long winter nights. A humorous and talented member of the coffeehouse community, versed in the repertoire of folklore or humorous stories, acted as the sole speaker. Also, peripatetic music players (Ashiq) were visiting coffeehouses, playing the saaz and singing epic folklore songs for money. The performer acted from the centre of the room, while the visitors gathered around him. This theatrical scenic arrangement is reproduced in the interior organisation of the coffeehouses, furnished along the interior walls and leaving the centre empty. This, in turn, facilitates verbal interaction with adjacent visitors as well as guests on the other side of the room. While the storytelling tradition has waned with modernisation, the interior arrangement of the coffeehouses remains intact, and the still peripatetic Ashiq occasionally perform during religious celebrations. Furthermore, the opportunity to partake of folklore, deep-rooted idiomatic expressions and jokes of the senior visitors particularly appeals to the younger artists frequenting the coffeehouses. In the words of one graphic artist:

I relate myself with the Grand Bazaar and its original environment and thus this coffeehouse, where I find lots of value. Meeting various groups of people of different ages and backgrounds and listening to original stories and memories told by elderlies takes me to the past. This oral history of my city inspires me in my artistic approach.

A stage artist similarly highlighted the role of the intergenerational interactions and knowledge sharing in the coffeehouses:

We gather here and talk about our artistic projects. We usually share our recent productions by reading our pieces out loud and asking others to give us feedback. The elderlies listen to us very carefully. They often correct us linguistically or remind us of the equal synonym form of the word if it is an old vocabulary.

In the coffeehouses, every topic and conversation can easily turn into a humorous story. In such a playful spirit (Oldenburg, 1989), every visitor of the coffeehouse becomes involved. All the same, the playfulness rests on subtle boundary drawings. It differentiates insider from outsider, playing on unwritten yet firm distinctions, linguistic codes, and behavioural patterns incorporated by the regulars. The threshold for entering into this community can be high and connected to notions of security and trust (which will be developed hereafter). Even so, the social texture of the coffeehouses can expand and develop, as illustrated with the recent cross-generational and cross-professional interchanges. 
In this process, coffeehouses become arenas for resistance against the hegemonic imposition and assimilation through cultural-linguistic Persianification. Then again, such potentially emancipating dynamics take place in a (more or less) mono-gendered environment, hence also reproducing broader patterns of gender segregation and sexism, despite (or perhaps enforced through) the intergenerational dynamics.

\subsection{Building Trust and Everyday Ethics for Survival}

Demanding the right of mother tongue schooling in official education has been a central agenda for Azerbaijani civil society in Iran, whilst it has been regarded as a security concern by the state authorities. In such a highly constrained political environment, where local identities are subject to marginalisation and public life is subject to systematic state monitoring, coffeehouses become arenas for 'non-collective' 'non-movements' (Bayat, 2010). As counterpublics, the coffeehouses allow subordinated groups to assert agency and political imaginations through mundane practices. They function as safe havens where precarious segments of the population may nurture cultural distinctions and quietly encroach the socio-political boundaries with limited public exposure. Resistance against state hegemony finds shape in cultural survival mechanisms (Moeini et al., 2018 , p. 5). How, then, are safety and trust established within the coffeehouses?

While the coffeehouses are public institutions, their publicness remains in flux. This flexibility allows them to occasionally function as exclusive and protected places. Unlike the branded and Westernised cafés, the low social and spatial profile of the coffeehouses obscures them from the monitoring gaze of the state. In this context, the owner of the coffeehouse often assumes a key role in the construction of the social and political atmosphere of the place, building security and safety from within. The owner may define the specific rules for the coffeehouse as an additional layer to the broadly recognised cultural rules and manners of the institutions ('regulating' the habitus of tea and hookah serving, smoking habits, sitting hierarchies). He selects the 'proper' visitors according to his own ethics, beliefs, and values. The role of the owner, however, varies among the establishments. In larger coffeehouses with more employees such as $\mathrm{Ba}$, the community is less closely-knit and the owner takes no role as overseer. All the same, safety mechanisms and distinctions of insider/outsider are established here too, within the texture of various groups of regulars.

In the smaller coffeehouse with a more limited clientele, however, the owner takes a direct role in overseeing the social environment. He keeps a close, friendly, and captivating relationship with the inner circle, which is a significant component in the feeling of homeliness, according to the participants. Thus, as a result of mutual friendship and observance of hierarchal patterns, a strong web of trust is built between the regulars and the owner. Although strangers are welcome to drop in, they are scarcely accepted among the insiders. When deemed necessary, the owner may reject a visitor, something which is considered essential for the safety of the place. To quote a graphic designer's words:

The rejection of the stranger-who might be a spy sent from the authorities - may happen obliquely and carefully such as avoiding serving hookah in order to make the stranger stay shorter. This manner creates a close circle of confidence inside the coffeehouse between the owner and us.

The owner's characteristics and attitudes are important parameters for the choice of frequenting a specific coffeehouse. More importantly, as the bonding between trusted members, owner, and place tightens, the regulars themselves come to take active responsibility for the security of the place. This creates a sense of collective care, vis-à-vis the place as well as the community. Many participants emphasised their interest in preserving the coffeehouse institutions and the socio-cultural norms and social ties which come with them. The sense of belonging resulting from such shared values can surface in practical undertakings, such as participating in the physical maintenance of the place and helping the social care of the regulars. In this capacity, coffeehouses provide informal social services, support, and solidarity, particularly for members with lower incomes and lack of support from the state. One of the long-standing traditions of coffeehouses is the aid for community members or their relatives in need. A 50-year-old participant who had frequented the place for more than 30 years echoed this view:

The relationships are friendly with a high degree of intimacy and respect to each other's socio-economic situation. For example, if someone is absent one day, others call him to check if everything is fine with him, if someone is sick, we may go to visit, or if someone needs money we collect some money to help. These kinds of activities make the coffeehouse a place different than other places; people care about each other.

\section{Or, as voiced by a young teacher:}

I have seen that the owner starts to collect money from the members for someone who is in need. No one asks for the reason or rejects. There is a high level of trust among people and toward the owner. I trust these people and this system more than the governmental charity institutions. Sometimes we even help the owner to repair the broken parts of the coffeehouse. We help him because we feel that this place belongs to us.

As is clear from the above, being a regular is paramount in the coffeehouses. The approval of owner and reg- 
ulars establishes trustworthiness. This acceptance may depend on several parameters, but chief among them is frequent presence, social involvement, and respectful conduct, especially concerning elderlies. Showing openness to others creates a sense of familiarity, trust, reliability, and care within the community of regulars. The delineation of insiders versus outsiders, the tacit sociocultural agreements, the mutual recognition and engagement of communal as well as individual needs hence constitute distinct coffeehouse ethics, observed and sustained on an everyday basis. Not only does frequenting the coffeehouse build on such norms, to draw on Cresswell (1996, p. 25), coffeehouse becomes the 'place' where social norms, definitions of rule, and deviance are produced. This specialisation of ethics or site of ethical responsibility (Popke, 2009) becomes the key component for constituting the coffeehouse as a safe place of counter-public sociability, solidarity, and resistance.

\section{Concluding Note}

The coffeehouses in this study function as counterpublics catering to cultural and ethnic-linguistic survival and everyday resistance, in the context of restricted public life and homogenising state policies. The limited public visibility, homeliness, and informality of the places coupled with cross-generational care and attachments make coffeehouses unique social institutions in contemporary Tabriz. Based on shared values and collective memory, owner and visitors contribute to the emplacement of socio-cultural meaning and identity. Such emplacement is upheld through everyday ethics, group affiliation, and othering, also contributing to a sense of security. In the politically constrained context of Iran, resistance and opposition in the coffeehouses hence surface as 'noncollective' 'non-movements' (Bayat, 2010). In this way, to draw on the concept of James Hoslton, marginalised ethnic groups configure new spaces of 'insurgent citizenship' (Holston, 1995).

Despite such emancipatory potentials of the coffeehouses, however, they remain mono-gendered social environments and hence problematical in any qualified sense as inclusive "subaltern counterpublics" (Fraser, 1990, p. 67). Despite the increasing access and political initiative of women in Iranian education and social activism of recent years, systematic control and legislation as well as broader cultural norms continue to severely constrain women's publicness. In this respect, coffeehouses are no exceptions. In Iran in general, and in non-Persian regions in particular, places asserting women's right to the city through public political action continue to be elusive.

\section{Acknowledgments}

The fieldwork for this research has been generously supported by Helge Ax:son Johnsons Foundation. I am particularly indebted to my research assistants Hamid M. B.,
Samad N., and Taher in facilitating the fieldwork. I also wish to thank the anonymous reviewers for their insightful comments.

\section{Conflict of Interests}

The author declares no conflict of interests.

\section{References}

Bayat, A. (2010). Life as politics: How ordinary people change the Middle East. Palo Alto, CA: Stanford University Press.

Braun, B., \& McCarthy, J. (2005). Hurricane Katrina and abandoned being. Environment and Planning D: Society and Space, 23(6), 802-809.

Crawford, M. (1995). Contesting the public realm: Struggles over public space in Los Angeles. Journal of Architectural Education, 49(1), 4-9.

Cresswell, T. (1996). In place/out of place: Geography, ideology, and transgression. Minneapolis, MN: University of Minnesota Press.

De Certeau, M. (1984). The practice of everyday life. Berkeley, CA: University of California Press.

Dehgan, K. (2017). Tajrobeye seh daheh bolandmartabeh-sazi dar Tabriz [Experience of three decades of high-rise building in Tabriz]. FasInameh-ye Memari va Sakhteman, 49, 46-52.

Encyclopædia Iranica. (2011). Coffeehouse. Encyclopædia Iranica. Retrieved from http://www. iranicaonline.org/articles/coffeehouse-qahva-kana

Fraser, N. (1990). Rethinking the public sphere: A contribution to the critique of actually existing democracy. Social Text, 1990(25/26), 56-80.

Gieryn, T. F. (2000). A space for place in sociology. Annual Review of Sociology, 26, 463-496.

Gilroy, P. (2003). Between the blues and the blues dance: Some soundscapes of the black Atlantic. In M. Bull \& L. Back (Eds.), The auditory culture reader (pp. 381-396). Oxford: Berg Publishers.

Habermas, J. (1991). The structural transformation of the public sphere: An inquiry into a category of bourgeois society. Cambridge, MA: MIT Press.

Hattox, R. (1985). Coffee and coffeehouses. Seattle, WA: University of Washington Press.

Holston, J. (1995). Spaces of insurgent citizenship. Journal of Planning Theory, 13, 35-51.

Kamrava, S. M. A. (2012). Shahrsazi-ye moaser-e Iran [Contemporary town planning in Iran]. Tehran: University of Tehran.

Kheiraldin, R., Taghvayi, A. A., \& Imani Shamlou, J. (2013). Tahlil-e tahavolat-e fazayi kalan-shahrha dar ertebat ba taghyirat-e gheymat naft dar Iran (Nomouneh mored-e motale'h: Kalan-shahr-e Tabriz) [Analysis of spatial developments in metropolises in relation to oil price changes in Iran (Case study: Tabriz metropolis)]. Majaleh-ye Memari va Shahrsazi-ye Iran, 20, 17-36. 
Matthee, M. (1994). Coffee in Safavid Iran: Commerce and consumption. Journal of the Economic and Social History of the Orient, 37(1), 1-32.

Mills, A. (2010). Streets of memory: Landscape, tolerance, and national identity in Istanbul. Athens, GA: University of Georgia Press.

Miraftab, F. (2012). Emergent transnational spaces: Meat, sweat and global (re)production in the heartland. International Journal of Urban and Regional Research, 36(6), 1204-1222.

Moeini, S. H. I., Arefian, M., Kashani, B., \& Abbasi, G. (2018). Urban culture in Tehran: Urban process in unofficial cultural spaces. Cham: Springer.

Nahidiazar, G. H. (2006). Seh mobarez-e mashrouteh [Three constitutional warriors]. Tabriz: Akhtar.

Nancy, J.-L. (2000). Being singular plural. Palo Alto, CA: Stanford University Press.

Oldenburg, R. (1989). The great good place: Cafes, coffee shops, community centers, beauty parlors, general stores, bars, hangouts and how they get you through the day. Saint Paul, MN: Paragon House.

Popke, J. (2009). Geography and ethics: Nonrepresentational encounters, collective responsibility and economic difference. Progress in Human Geography, 33(1), 81-90.
Razmi, M. (2018). Revayati tarikhi az ghahveh-khanehaye Tabriz [A historical narrative of Tabriz coffee houses]. Işıq, 1(2), 114-127.

Sadighi, S., \& Salek, R. (2018). Tahlil-e avamel moasser bar tashdid-e kalayi shodan-e fazay-e shahri az didgah shahrvandan, motale'-ye Moredi: Kalanshahr-e Tabriz [Analysis of factors affecting the rise of commodification of urban space from the perspective of citizens (The case study: Tabriz metropolitan)]. Pazhouheshha-ye Joghrafiya-ye Barnamehrizi-ye Shahri, 6(4), 791-807.

Warner, M. (2002). Publics and counterpublics (Abbreviated version). Quarterly Journal of Speech, 88(4), 413-425.

Wohl, S. (2017). The Turkish tea garden: Exploring a "third space" with cultural resonances. Journal of Space and Culture, 20(1), 56-67.

Zangiabadi, A., \& Mobaraki, O. (2012). Barasi-e avamele moasser bar sheklgiri-ye hashie-neshini-e shahr-e Tabriz va payamadha-ye an, motale'-ye moredi: Mahalat-e Ahmadabad, Koyebeheshti, Khalilabad [Analysis of effective factors in creation of slums in Tabriz and their consequences. Case study: Ahmadabad, Koyebeheshti, khalilabad]. Joghrafiya va Barnamehrizi-ye Mohiti, 23(1), 67-80.

\section{About the Author}

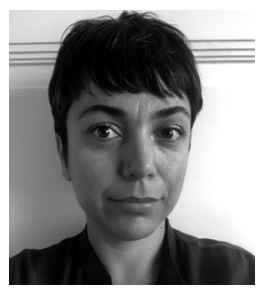

Laleh Foroughanfar is an Architect and Urban Designer by training and currently a PhD candidate at Lund University. In her PhD thesis, she explores the everyday life of a post-industrial peripheral street emerging from the intersections of global migration and urban marginalisation in Malmö, Sweden. With a point of departure in critical ethnographty, the thesis elucidates negotiations and spatial interventions in processes of place-making among migrants, in relation to neo-liberal capitalism and precarious urbanism. 